\title{
Impacts of Income Distribution, Taxes, and Direct Democracy on Foundation Activity
}

\author{
Martin Blickenstorfer - Hans Lichtsteiner
}

Published online: 22 November 2014

(C) International Society for Third-Sector Research and The Johns Hopkins University 2014

\begin{abstract}
Although charitable foundations play an important role in modern Western civil societies, knowledge about them and the factors that encourage their prevalence is still quite limited. The relevant literature acknowledges that Switzerland has proven a fertile ground for foundation growth, and in this paper, we develop and empirically test a model in order to examine the effects of the country's economic and political incentive structure on foundation activity. We find that alongside the required income level that is an important determinant of foundation prevalence, tax incentives, and direct democracy have significant influence on individuals' philanthropic behavior, as each account for approximately $10 \%$ of the variance in the model presented here.
\end{abstract}

Résumé Bien que les organismes de bienfaisance jouent un rôle important dans la société civile occidentale moderne, les connaissances sur ces derniers et les facteurs favorisant leur prévalence sont encore assez limitées. Les publications pertinentes reconnaissent que la Suisse s'est avérée un terrain propice à la croissance de ces organismes, et dans cet article, nous développons et testons de manière empirique un modèle afin d'étudier les effets de la structure d'incitation économique et politique du pays sur les activités des organismes. Nous constatons qu'en même temps que le niveau de revenu requis, qui est un facteur déterminant de la prévalence des organismes, les avantages fiscaux et la démocratie directe ont une influence significative sur le comportement philanthropique des individus, puisque chaque facteur constitue environ dix pour cent de la différence dans le modèle présenté ici.

\footnotetext{
M. Blickenstorfer $(\bowtie) \cdot$ H. Lichtsteiner Verbandsmanagement Institut (VMI), University of Fribourg, P.O. Box 1559, 1701 Fribourg, Switzerland

e-mail: martin.blickenstorfer@bluewin.ch

H. Lichtsteiner

e-mail: hans.lichtsteiner@unifr.ch
} 
Zusammenfassung Obwohl gemeinnützige Stiftungen in modernen westlichen Bürgergesellschaften eine wichtige Rolle spielen, ist die Kenntnis über sie und die Faktoren, die ihre Verbreitung begünstigen, noch immer sehr beschränkt. In der einschlägigen Literatur wird bestätigt, dass die Schweiz günstige Bedingungen für das Wachstum von Stiftungen bietet. In diesem Beitrag entwickeln und testen wir empirisch ein Modell, um zu erforschen, inwieweit sich die wirtschaftliche und politische Anreizstruktur in diesem Land auf die Aktivitäten von Stiftungen auswirkt. Wir kommen zu dem Ergebnis, dass neben dem notwendigen Einkommensniveau, das eine wichtige Determinante für die Verbreitung von Stiftungen darstellt, Steueranreize und eine direkte Demokratie das philanthropische Verhalten einzelner Personen wesentlich beeinflussen, da beide Faktoren jeweils rund 10 Prozent der Abweichung in dem hier präsentierten Modell ausmachen.

Resumen Aunque las fundaciones benéficas desempeñan un importante papel en las sociedades civiles occidentales modernas, el conocimiento de las mismas y de los factores que alientan su predominio sigue siendo bastante limitado. El material publicado pertinente reconoce que Suiza ha demostrado ser un fértil terreno para el crecimiento de las fundaciones y en el presente documento desarrollamos y probamos empíricamente un modelo con el fin de examinar los efectos de la estructura de incentivos políticos y económicos del país sobre la actividad de las fundaciones. Encontramos que, junto con el nivel de ingresos requerido, que es un importante determinante del predominio de las fundaciones, los incentivos fiscales y la democracia directa tienen una influencia significativa sobre el comportamiento filantrópico de los individuos, ya que cada uno de ellos representa el diez por ciento aproximadamente de la varianza en el modelo aquí presentado.

Keywords Foundations - Direct democracy - Taxes - Civil society - State failure

\section{Introduction}

Charitable or public benefit foundations play an important role in modern Western civil societies. Their significance is reflected not only in the wide range of activities in which they are involved but also in their steadily increasing number over the past decades (Anheier and Daly 2007b; Hopt et al. 2009). Although they are considered to be one of the oldest remaining organizational forms of civic involvement, and despite the continuous growth of the foundation sectors in many European and North American countries, research dedicated to foundations has until recently remained a relatively neglected area within the extensive literature on nonprofit organizations (Anheier 2001, pp. 35-36; Prewitt 2006, p. 355). To a certain extent, this lack of attention may be attributed to the fact that research on foundations is highly multidisciplinary, as such organizations may be considered from a legal, sociological, or economic perspective (Purtschert et al. 2003, p. 2). In addition, research on foundations tends to be fragmented, due to the very nature of the topic. Foundation sectors and their organizations are strongly characterized by the 
particular cultural and legal framework in which they operate. This brings definitional complications, as the concept of foundations is perceived and defined differently across countries. In fact, two of the most comprehensive comparative research projects conducted in the field of nonprofit organizations, the Johns Hopkins Comparative Nonprofit Sector Project (CNP) and, focusing more specifically on foundations, Visions and Roles of Foundations in Europe, emphasize the multidisciplinarity and fragmentation of the area (Anheier and Daly 2007b; Salamon and Anheier 1992).

Relatively long periods of political stability, democratization processes in countries previously ruled autocratically and high levels of economic prosperity have encouraged a continuous growth of foundation numbers in recent years (Anheier 2001). With respect to these criteria, Switzerland serves as a typical example, its foundation numbers having increased considerably and regularly in the second half of the 20th century. It now has an exceptionally high foundation density (the number of foundations in relation to the population) compared with other nations (Anheier 2006; Purtschert and von Schnurbein 2006; Riemer 2001). But a closer look at the distribution of foundations in Switzerland shows considerable differences even within the country, foundation density varying almost by a factor of six between the 26 cantons that constitute the Swiss Confederation (Eckhardt et al. 2014). What makes the case of Switzerland particularly intriguing is the country's federal structure and the deeply rooted principle of subsidiarity, which delegates public tasks and political decisions to a level which is as close to the citizen as possible (Helmig et al. 2010; Kirchgässner and Pommerehne 1996). While there is little doubt that these institutional settings have greatly impacted the Swiss nonprofit sector, their effects have not yet been addressed by nonprofit research in the specific context of foundations. Little is known about how the extensive direct democratic rights, taxation, and federalism each influence the motives of individuals wishing to establish a public benefit foundation. As the will of the founder stands at the beginning of every foundation, the motives that drive individuals to set up a foundation play a crucial role. Within an extensive literature on fundraising and charitable giving, donor motives have been widely examined (Bekkers and Wiepking 2011; Wiepking and Bekkers 2012). The number of contributions devoted specifically to founders, and the motives that drive them to establish a foundation, is much more limited, however. The studies by Timmer (2005) for Germany and Helmig and Hunziker (2007) for Switzerland offer insights into founders' motives in general. Petrovits (2006) focused on the underlying rationale of US corporate foundations and Pedrini and Minciullo (2011) analyzed Italian corporate foundations challenged by multiple stakeholder interests. The most recent contributions to research on corporate foundations come from Switzerland (Eckhardt et al. 2014; Schatzmann 2014). The effects of the wider economic and institutional settings are not addressed, however. In this context, the aim of the present article is to shed light on the effects of the economic and political incentive structure on individuals' decisions to engage in philanthropic activity. Switzerland provides an ideal testing field due to the varying expressions of the political and economic factors of interest between Swiss cantons (Frey 1997). 
The article is structured as follows: the next section "Theoretical background" discusses the theoretical considerations that lead us to the hypotheses and the model suggested in the "Model and data" section that follows. The subsequent section provides the results from the empirical test of the model and discusses their implications. The conclusion includes reflections on future research.

\section{Theoretical Background}

The establishment of a foundation, which is the endowment of an asset for a specific purpose, requires a level of wealth not achieved by all social strata (Anheier 2003). Empirical evidence indicates that wealthy people are not only more prone to making donations than members of the middle class but they also make up a significant proportion of founders (Helmig and Hunziker 2007; Ostrower 1997; Sargeant 1999; Timmer 2005). Furthermore, the establishment of foundations is encouraged by additional income or sudden increase in wealth (Helmig and Hunziker 2007; Timmer 2005). Just as the development of the economy impacts the growth of many foundations' assets and thus their success, it also influences the establishment of new foundations (Eckhardt et al. 2012). This is illustrated by the close link between the emergence of new foundations and market trends. The number of new foundations established is accurately reflected in the development of the Swiss Market Index (Eckhardt et al. 2011). Thus, the surplus generated by favorable economic development represents additional wealth which acts as a driver of foundation activity.

As noted in the introduction, specific literature on the motives of founders is scarce. However, the few surveys with a focus on founders show that many of their motives are largely congruent with those previously identified by studying donor motives (Frank 1996; Haibach 2006; Helmig and Hunziker 2007; Prewitt 2001; Timmer 2005). When considering engaging in philanthropic activities, individuals are rarely driven by a single motive but rather by a bundle of motives (Cooper 1994, p. 79; Lindahl and Conley 2002, pp. 92-93; von Schnurbein 2010, p. 20). While it is impossible to compile an exhaustive list, the literature distinguishes two general categories of motives, namely altruistic and self-interested motives, which may be considered the two extremes of a continuum (Lindahl and Conley 2002, p. 93; Monroe 1996; Prewitt 2001, p. 346 ff.). Examples of primarily altruistic motives include identification with a cause, a moral imperative, and the desire to give something back to society, whereas possible motives based primarily on self-interest are guilt, self-actualization, and tax benefits (Andreasen and Kotler 2003, pp. 199-202; Haibach 2006, pp. 167-168; Helmig and Hunziker 2007, p. 17; Timmer 2005, p. 28).

Most authors acknowledge that self-interest is a part of a donor's or founder's motivation to engage in philanthropic activity. However, many authors focus primarily on altruistic motives. This is unsurprising, and can to a considerable extent be ascribed to social desirability, as it is to be expected that individuals engaging in philanthropic activity are likely to stress the altruistic motives behind their actions. In practice, altruism is rarely the sole motive for philanthropic activity and 
self-interested motives on the part of the donor must be taken into consideration (Andreoni 1989, 1990). Ostrower (1997) shows that donors are motivated by the prestige that comes with belonging to a given philanthropic elite. Establishing a foundation is, after all, a publicly visible act (Anheier and Daly 2007a, p. 3). Prewitt (1999) argues that a large portion of charitable giving disproportionately benefits better-off social strata and Odendahl (1990) goes as far as to identify self-interest as the dominating motive behind philanthropic action, summarizing one of the principal findings in the opening sentence: "Elite American philanthropy serves interests of the rich to a greater extent than it does the interests of the poor, disadvantaged or disabled".

As a specific example of self-interested motivations relevant to the context of philanthropy, the effects of tax benefits have been considered by a number of studies. Auten and Rudney (1990), Randolph (1995) and Auten et al. (2002) find that tax levels can affect charitable giving: individuals tend to time their contributions so as to maximize tax savings and either make donations in years in which the tax burden is particularly high or split their contributions over several years in order to take advantage of tax benefits. These findings support the argument that tax considerations do play their part in philanthropists' intentions to establish foundations. Due to Switzerland's federal structure and the local authorities' tax jurisdiction, taxes are levied at a federal, cantonal, and communal level. According to the Swiss tax legislation, contributions to charitable foundations benefit from a deduction of up to $20 \%$ on taxable income at the federal tax level. It is left to the cantons to increase or decrease the deductible share for cantonal taxes. While one canton has increased this share to $100 \%, 22$ of the 26 Swiss cantons have adopted the $20 \%$ specified at the federal level and three cantons have limited the deductible share to $10 \%$ or less (proFonds 2011, 2013). As Switzerland has relatively low wealth tax rates, it is apparent that tax benefits on income taxes could provide an incentive to engage in philanthropic activity, leading us to the following hypothesis:

Hypothesis 1 High tax rates encourage charitable foundation activity.

Since higher income will increase both the absolute amount of tax payments and the relative tax load, due to tax progression, we also hypothesize as follows:

Hypothesis 2 The higher the income tax in a given canton, the stronger the effect of Hypothesis 1 will be.

Redistribution between social strata is part of the mission of many charitable associations and foundations, even in societies with extensive social safety nets. While charity in the traditional and limited sense of redistribution from wealthy to poor may not be their sole purpose, many foundations in Switzerland and in other Western welfare states contribute significantly to closing wealth or income gaps, for instance by providing aid in funding childcare or education (Anheier and Daly 2007b). Similarly, foundations contribute to granting access to art, leisure, and education to underprivileged social strata as well as reducing inequality with respect to professional, career, and other opportunities. By acting in such a role, foundations either compete with the state's redistribution mechanism or complement it. If an acting political system strives to reduce economic or social equality, it can delegate 
this task of leveling inequality to charitable organizations. If the state fails in its task by contributing less to reducing the wealth gap than expected by its citizens, the latter can choose to support public utility organizations and let these act in the state's stead (Weisbrod 1988). To what extent charitable foundations manage to fulfil this role has been discussed in the past. Prewitt (1999), for instance, questions whether foundations are more qualified to redistribute funds efficiently from richer to poorer social strata than are the public authorities. From an individual perspective, a person willing to support a charitable cause with a share of his financial resources (income or wealth) has two fundamentally different options: The individual may do so by paying his taxes and thus leaving the fulfillment of his personal goals to the state; alternatively he may do so by either establishing his own or supporting an existing private organization of public benefit. If the state grants tax breaks for supporting a public utility cause, the two described alternatives are substitutes. In this case, the individual's choice for one or the other ultimately depends on the extent to which he can influence the government's spending decision. Empirical evidence from Switzerland shows that citizens are quite willing to contribute to the provision of public goods and redistribution of income, especially if they have a say in the political process, for example by means of direct democratic instruments allowing them to supervise and if necessary directly influence the decisions taken (Feld and Frey 2010; Frey 1997; Frey and Torgler 2007; Kirchgässner 2007). Kinsey (1992) and Smith (1992) find this to be true for the United States as well. From an agency theory perspective (Jensen and Meckling 1976), one may argue that the easiest way for an individual to address public welfare, issues of social inequality, and other public benefits is to pay taxes-under the condition of sufficient control over the public policy making process. Tax payers may have at their disposal direct democratic instruments allowing them to take corrective action. They can revert to them in case the funds are not allocated in a manner intended by them or if they feel that the government is failing to address the challenges on hand efficiently. If, however, philanthropic citizens cannot make use of such direct democratic instruments and fear that the authorities might not use the funds in their own interests, they will favor taking control and establishing a charitable foundation. This grants the founders full control by allowing them to specify the purpose of the foundation and the extent of the funds dedicated to the specific purpose and even to take part in the implementation of the foundation's goals. This gives us a third hypothesis:

Hypothesis 3 Extensive direct democratic rights with regard to public spending have a dampening effect on charitable foundation activity.

As with Hypothesis 2, it is plausible to assume that the larger the amount of tax a citizen pays, the more interested that citizen will be in having a say in public spending. This leads to a further hypothesis:

Hypothesis 4 The higher the tax load in a given canton, the stronger the effect of Hypothesis 3 will be.

The theoretical considerations in this section support the assumptions that the economic and political incentive structure influences foundation activity in a variety 
of ways. In the following section, a model is presented which aims to capture the influence of these factors on charitable foundation activity in Switzerland.

\section{Model and Data}

Based on the theoretical considerations in the previous section, we have developed a model which makes it possible to test empirically the hypotheses formulated in the context of the 26 cantons that make up the Swiss Confederation.

\section{Dependent Variable}

The model presented here analyzes the effects of economic and political factors on the prevalence of charitable foundations across Switzerland. Foundation density (FD) appears to be an adequate measure for this purpose. It is defined as the number of charitable foundations per 10,000 residents of a canton. The data used here represent the foundation sector at the end of 2011 and have been taken from the Swiss Foundation Report (Eckhardt et al. 2012) which in turn builds on the data set of the national and cantonal registers of commerce.

\section{Independent Variables}

As argued in the previous section, foundation activity is closely linked to the development of the economy. In order to capture the development of the relevant wealth components, national income is the obvious choice of indicator. In the Swiss national accounts data, this measure was published until 2005 before being replaced by the more common GDP. The latter indicator, although closely related to national income, includes certain components (e.g., subsidies and depreciation) that are not of relevance in the present context. We thus include net national income per capita (NI) as a variable modeling the necessary income component of foundation activity. Data are logarithmized in order to account for the considerable variance among net national income figures for the different cantons. We have relied on the latest available dataset, from 2005, provided by the Swiss Statistics Office (BfS 2014b).

In order to account for the effects of tax levels on foundation activity, as set out in the theoretical discussion, a variable measuring the tax burden needs to be introduced into the model. For this purpose, the combined index of the load of income and wealth taxes per canton (TL) will be used where the base for the index (100) represents the average Swiss tax load. The data used provide values for 2006 and are the most recent data published by the Swiss Statistics Office (BfS 2014a). With the introduction of a new fiscal equalization scheme between the cantons as of 2007, the main purpose of this index, to serve as a basis for further measures related to fiscal equalization, has become obsolete and the Swiss Statistics Office has ceased its publication. No comparable indicator has been published since then.

Finally, the effects of the possibility of intervention through direct democratic rights need to be included in the model. Depending on the focus of the question at hand, it is conducive to focus on a specific aspect of direct democracy rather than on 
a general index (Feld and Matsusaka 2003; Stutzer 1999). Among the various direct democratic instruments available to Swiss citizens, one of the primary interests in the present context is the possibility to influence public spending. For this reason, we revert to the index of fiscal referendum rights (RR) developed by Stutzer and Frey (2000) as a third independent variable. The index is determined by evaluating the number of signatures required to submit a fiscal referendum (the lower the better), the timeframe granted to collect the necessary signatures (the longer the better), and the minimum amount that may be disputed (the lower the better). The index attributes a value between 1 and 6 for each of the 26 Swiss cantons: higher values indicate lower barriers for the submission of a fiscal referendum and thus more extensive fiscal referendum rights. The data used is drawn from an updated version of the index published by Fischer (2005) and, although comparatively old, still accurately reflects the current situation in Switzerland today as the arrangement of direct democratic rights has not witnessed any fundamental changes in recent years.

The variables outlined in this section give the following model, which we will now test empirically:

$$
\mathrm{FD}=a \cdot \mathrm{NI}+b \cdot \mathrm{TL}+c \cdot \mathrm{RR}+e .
$$

\section{Results and Discussion}

Using Ordinary Least Squares (OLS) regression analysis, a method well suited to the analysis of linear or linearizable effects, we tested the empirical model developed in the previous section. Table 1 summarizes the sample's descriptive statistics as well as the Pearson correlation coefficients for the variables examined. It is apparent that apart from the statistically significant correlation between net national income (logarithmized) and foundation density on one hand and a weak correlation between net national income and tax load on the other hand, none of the other independent variables appear to be connected, nor does there seem to be any connection between them and the dependent variable.

Table 1 Descriptive statistics and Pearson correlation coefficients $(N=26)$

\begin{tabular}{|c|c|c|c|c|c|}
\hline Variable & Mean (SD) & $\begin{array}{l}\text { Median } \\
\text { (Min, Max) }\end{array}$ & $2(\mathrm{NI})$ & $3(\mathrm{TL})$ & $4(\mathrm{RR})$ \\
\hline 1. Foundation density in 2011 (FD) & $17.5(8.1)$ & $16.0(7.9,46.1)$ & $0.66^{* *}$ & 0.06 & -0.10 \\
\hline $\begin{array}{l}\text { 2. Logarithmized net national } \\
\text { income }(\mathrm{NI})\end{array}$ & $10.9(0.3)$ & $10.8(10.6,11.7)$ & & -0.38 & 0.29 \\
\hline 3. Tax load (TL) & $107.1(25.2)$ & $113.9(50.3,146.5)$ & & & -0.16 \\
\hline 4. Fiscal referendum rights (RR) & $3.7(1.2)$ & $4.0(1.0,5.0)$ & & & \\
\hline
\end{tabular}

Significance levels (two-tailed): $* *>99 \%$ 
Table 2 OLS estimates for factors influencing foundation density $(N=26)$

\begin{tabular}{|c|c|c|c|c|c|}
\hline Independent variables & \multicolumn{5}{|c|}{ (standardized beta coefficients) } \\
\hline Net national income $(\mathrm{NI})$ & $0.66^{* * *}$ & $0.80 * * *$ & $0.88 * * *$ & $0.95^{* * *}$ & $0.93 * * *$ \\
\hline Tax load (TL) & & $0.36^{*}$ & $0.35^{*}$ & $0.28 *$ & $0.27 *$ \\
\hline Fiscal referendum rights (RR) & & & $-0.30 *$ & $-0.37 * *$ & $-0.37 * *$ \\
\hline Interaction effect & & & & $0.36^{* *}$ & $0.32 *$ \\
\hline \multicolumn{6}{|l|}{$\mathrm{TL} \times \mathrm{NI}$} \\
\hline Interaction effect & & & & & 0.10 \\
\hline \multicolumn{6}{|l|}{$\mathrm{TL} \times \mathrm{RR}$} \\
\hline$F$ value & $18.64 * * *$ & $14.04 * * *$ & $12.49 * * *$ & $15.13 * * *$ & $12.09 * * *$ \\
\hline$R^{2}$ & 0.44 & 0.55 & 0.63 & 0.74 & 0.75 \\
\hline Adjusted $R^{2}$ & 0.41 & 0.51 & 0.58 & 0.69 & 0.69 \\
\hline
\end{tabular}

Significance levels (two-tailed): $* * *>99.9 \%, * *>99 \%, *>95 \%$

Table 2 provides the OLS estimates for each of the factors influencing foundation density in Swiss cantons; the values represent the standardized beta coefficients. In addition to the variables defined in the previous section, two interaction effects can be identified. Although only one of these two is statistically significant (interaction between net national income and tax load), the interaction between fiscal referendum rights and tax load is also presented here because it suggests some interesting insights, as will be seen below.

We argued earlier that the establishment of a charitable foundation depends on available assets. This is confirmed in Model 1, presented in Table 2, which shows that net national income has a statistically significant positive effect on foundation density and that it alone accounts for over $40 \%$ of variance. The influence of net national income on foundation density remains stable and strong when additional variables are gradually introduced, as shown in subsequent models. Interestingly, the assets granted for the establishment of a foundation seem to emanate from increased income rather than existing wealth. Various measures of wealth and its distribution were tested in the model, none of which managed to contribute noticeably to explaining the variation in foundation density between cantons. The results thus contradict a popular belief that existing wealth is the main driver of foundation activity.

Although the model was tested using the most recent data available, an additional model was tested for the sake of timeliness, using GDP from 2011 as a viable proxy for national income $(r=0.86, p<0.01)$, even though the latter indicator more accurately fits the purpose of the current study. The resulting model loses some of its explanatory power but it remains statistically significant and confirms a positive influence of income on foundation density.

Tax load accounts for an additional $11 \%$ of variance, increasing the coefficient of determination to $55 \%$. Model 2 shows that tax load has a significantly positive effect on foundation density. This supports Hypothesis 1 which states that high tax rates encourage foundation activity. As income taxes provide the greatest incentive 
to save taxes, the results also support the argument that foundations do seem to result from additional income rather than wealth, since the latter holds no appreciable tax-saving potential.

Model 3 introduces fiscal referendum rights, which explain an additional $10 \%$ of the variance. Comparable to the effects of tax load in terms of magnitude, fiscal referendum rights display a significantly negative effect on foundation density, thus confirming the dampening effect of direct democratic rights assumed in Hypothesis 3. Thus, individuals are driven to establish a charitable foundation only if they feel that they have insufficient options to influence how the taxes paid will be spent. In cantons with comparatively underdeveloped fiscal referendum rights, the prevalence of foundations may be interpreted as a vote of no confidence in the authorities with respect to public welfare spending or the provision of other public goods. Put more positively, the results from Model 3 support the arguments of Frey (1997), Frey and Torgler (2007), Kirchgässner (2007) and Feld and Frey (2010) that citizens with extensive direct democratic rights are more ready to contribute to public spending than citizens without such rights.

Analysis of the present model yields two notable interaction effects. There is, first, a significantly positive interaction between tax load and net national income and also a second interaction between tax load and fiscal referendum rights. This falls only slightly short of statistical significance at the $90 \%$ level. The first effect positively moderates the influence of additional income on foundation density, thus supporting Hypothesis 2 and further emphasizing the contention that high tax rates act as an incentive for individual philanthropic behavior. The second interaction, although not statistically significant, represents a positive moderating effect of tax load on the influence of fiscal referendum rights. This means that the higher the tax rates in a given canton, the more pronounced the dampening effect of fiscal referendum rights on foundation density, a finding which both confirms Hypothesis 4 as a tendency and also supports Hypothesis 3. If individuals are to leave the allocation of their tax contributions to the authorities, they demand the necessary supervisory instruments. The higher the tax payments are, the more important this becomes.

Empirical studies of the Swiss nonprofit sector typically yield patterns that can differ considerably between the German-speaking area on one hand and the Frenchand Italian-speaking regions on the other. Stadelmann-Steffen et al. (2010) show this to hold true for giving and volunteering, while Helmig et al. (2010) confirm it with respect to organizations' areas of activity. Applied to the present context, a comparison shows significant differences in the extent of fiscal referendum rights, with German-speaking cantons offering more extensive fiscal referendum rights than their French- and Italian-speaking counterparts. Interestingly, when considered separately with respect to the model at hand, the results for the linguistic regions reveal the same tendency: regardless of the sample's mean level of fiscal referendum rights, an increase in these rights produces a dampening effect on foundation density, thus supporting Hypothesis 3.

The models in Table 2 were estimated using the latest data available and represent a snapshot for the year 2011. As reported by Auten and Rudney (1990), charitable giving can vary considerably over time as a result of changes in income 
or tax policy. Furthermore, the variability in generosity was found to be greater at higher income levels. This would apply to the context of foundations in particular, since the establishment of foundations usually involves significantly greater sums than does a simple donation to charity. Accordingly, in order to validate the results in Table 2, the model was tested additionally for 2000 and 2005 based on the Swiss Foundation Report (Eckhardt et al. 2011) and data obtained from the cantonal registers of commerce for the number of foundations and on official statistics for all the other variables except fiscal referendum rights (BfS 2014a, b). Table 3 provides the descriptives and Table 4 summarizes the results. Although these show that explanatory power increases over time, the figures for 2000 already display a similar pattern to the one visible in Table 2. Although the margins for error tend to be slightly higher than in 2005 or 2011, the results support both hypotheses formulated above.

\section{Conclusion and Further Research}

The present study has explored factors influencing charitable foundation prevalence in Switzerland in the specific context of federalism and taxation. Switzerland boasts a high foundation density by international comparison but these foundations are unevenly distributed among the 26 cantons that constitute the Swiss Confederation. Switzerland's federal structure grants cantons considerable autonomy which extends to taxation and the implementation of direct democratic rights, making the country an ideal environment in which to analyze the effects of these factors on foundation activity. We have developed a model which takes into consideration the fact that a potential founder requires a certain wealth or income level in order to establish a foundation, and assumes that, although they are interested in taking advantage of tax benefits, individuals are quite willing to contribute to the provision of public goods through tax payments, provided they enjoy fiscal referendum rights to supervise the spending of their tax francs. The model was empirically tested using OLS regression analysis and the results confirm that income is indeed a powerful driver of

Table 3 Descriptive statistics and Pearson correlation coefficients $(N=26)$

\begin{tabular}{lcccccr}
\hline Variable & & Mean (SD) & $\begin{array}{l}\text { Median } \\
\text { (Min, Max) }\end{array}$ & 2 (NI) & 3 (TL) & $4(\mathrm{RR})$ \\
\hline 1. Foundation density (FD) & 2000 & $11.3(5.3)$ & $9.9(4.4,28.6)$ & 0.36 & 0.15 & -0.13 \\
& 2005 & $14.7(6.7)$ & $13.8(7.2,38.4)$ & $0.63^{* *}$ & 0.09 & -0.10 \\
2. Logarithmized net & 2000 & $10.8(0.2)$ & $10.7(10.5,11.3)$ & $-0.64^{* *}$ & 0.34 \\
national income (NI) & 2005 & $10.9(0.3)$ & $10.8(10.6,11.7)$ & $-0.40^{*}$ & 0.29 \\
3. Tax load (TL) & 2000 & $100.2(18.5)$ & $101.6(56.3,128.7)$ & - & $-0.46^{*}$ \\
& 2005 & $107.8(28.7)$ & $112.7(49.5,165.1)$ & & -0.19 \\
4. Fiscal referendum & 2000 & $3.7(1.2)$ & $4.0(1.0,5.0)$ & & & \\
rights (RR) & & & & & & \\
\hline
\end{tabular}

Significance levels (two-tailed): $* *>99 \%, *>95 \%$ 


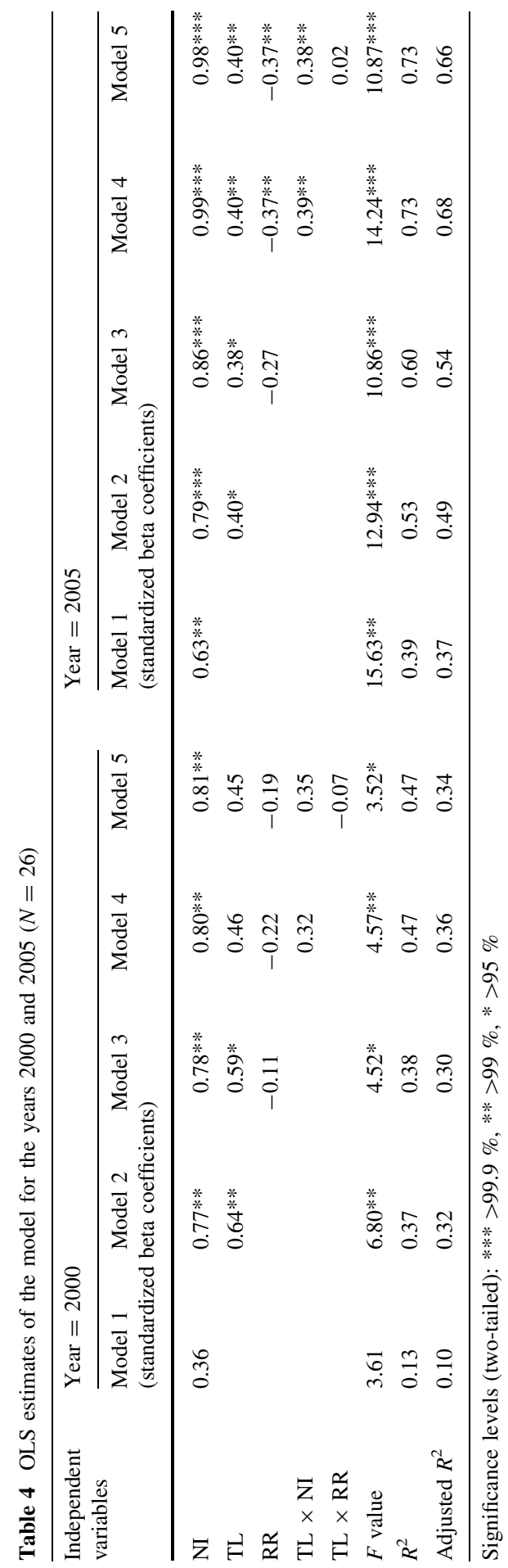


foundation activity, not only because it supplies the necessary assets to establish a foundation but also because under Swiss tax legislation founders are granted substantial tax breaks on income taxes, which, due to their progressive rates, offer considerable potential for optimization. This finding is supported by the fact that a heavier tax load positively influences foundation density. Unlike estate taxes levied in other countries, wealth, estate, or inheritance taxes in Switzerland provide only a negligible incentive to part with one's assets at a younger age. Furthermore, the results also show that potential philanthropists in cantons with extensive direct democratic rights are less reluctant to leave the provision of public goods or social welfare to the public authorities, because the possibility of a fiscal referendum offers them a certain level of control over public spending. Indeed, taxpayers that do not trust the public authorities to invest their tax francs sensibly are particularly sensitive to the real effect of varying tax rates between cantons. The high coefficient of determination here suggests that the model developed in this article provides helpful insights into the economic and political factors that determine charitable foundation activity in Switzerland.

By examining the specific case of Switzerland, the present contribution addresses a number of topics that offer possibilities for further research. The theory of state failure has been widely reverted in order to explain the emergence of public benefit organizations in various fields. The present study applies the theory to the specific context of foundations where it enables us to identify areas at the institutional, political, and economic levels where policy makers have the opportunity to influence and ultimately avoid state failure. The context of Switzerland represents a special case in a sense that citizens with their extensive direct democratic rights dispose of ample possibilities to voice their concerns with government decisions. Therefore, the framework suggested in the present study ought to be validated in different institutional settings. As will be discussed below, data from other countries with a comparable federal structure indicates similar patterns to the ones observed in the Swiss case.

The significance of more or less permissive political and institutional settings has been discussed in the literature (Anheier and Ben-Ner 2003; Powell and Steinberg 2006). In this context, the present study contributes to a better understanding of political influencing factors on the size and shape of the third sector. By considering direct democratic rights, it offers insights into the participation of citizens on an individual level, an aspect, which until now has been less widely covered. The literature suggests that Switzerland offers favorable conditions for the establishment of charitable foundations. With its analysis of the effects of varying institutional settings at a cantonal level, the present contribution provides insights into how economic and political factors affect foundation activity. As the insights gained from the present study are difficult to generalize in their entirety, analysis of the pertinence of these factors, both in similar and divergent political and economic environments, offers interesting possibilities for further research. First, there is a need to test whether the conclusions from this study can be extended to other countries. A cursory analysis of data for the United States and Germany also shows significant effects of income on foundation density. For the United States, which has a federal structure comparable to that of Switzerland, including extensive direct 
democratic rights and varying tax load from state to state, the data hint at a similar pattern as that found in the present study. In addition to this, it would also be of interest to identify further or alternative factors that influence foundation activity in countries with fewer direct democratic instruments. Having long benefitted from high political stability, economic growth, and prosperity, Switzerland displays relatively consistent results for the time period considered. It should now prove profitable to analyze how foundation activity has developed in countries that have experienced greater economic and political changes and to examine how these changes have impacted the drivers of foundation activity identified for the Swiss context.

\section{References}

Andreasen, A. R., \& Kotler, P. (2003). Strategic Marketing for Nonprofit Organizations (6th ed.). New Jersey: Prentice Hall.

Andreoni, J. (1989). Giving with impure altruism: Applications to charity and ricardian equivalence. Journal of Political Economy, 97(6), 1447-1458.

Andreoni, J. (1990). Impure altruism and donations to public goods: A theory of warm-glow giving. The Economic Journal, 100(401), 464-477.

Anheier, H. K. (2001). Foundations in Europe: a comparative perspective. In A. Schlüter, V. Then, \& P. Walkenhorst (Eds.), Foundations in Europe (pp. 35-81). Bertelsmann Foundation, London: Society management and law.

Anheier, H. K. (2003). Das Stiftungswesen in Deutschland: Eine Bestandesaufnahme in Zahlen. In Handbuch Stiftungen (Ed.), Bertelsmann Stiftung (pp. 43-85). Wiesbaden: Gabler.

Anheier, H. K. (2006). Stiftungen in Europa: Resultate eines Ländervergleichs. In P. Egger, B. Helmig, \& R. Purtschert (Eds.), Stiftung und Gesellschaft: Eine komparative Analyse des Stiftungsstandortes Schweiz (pp. 57-90). Basel, Genf, München: Helbing \& Lichtenhahn.

Anheier, H. K., \& Ben-Ner, A. (2003). The study of nonprofit enterprise: Theories and approaches. New York: Springer.

Anheier, H. K. \& Daly, S. (2007a). Philanthropic foundations in modern society. In H. K. Anheier \& S. Daly (Eds.), The politics of foundations. A comparative analysis (pp. 3-26). London, New York: Routledge.

Anheier, H. K., \& Daly, S. (2007b). The politics of foundations. A comparative analysis. London, New York: Routledge.

Auten, G. E. \& Rudney, G. (1990). The variability of individual charitable giving in the US. Voluntas: International Journal of Voluntary and Nonprofit Organizations, 1(2), pp. 80-97.

Auten, G. E., Sieg, H., \& Clotfelter, C. T. (2002). Charitable Giving, Income, and Taxes: An Analysis of Panel Data. The American Economic Review, 92(1), 371-382.

Bekkers, R. \& Wiepking, P. (2011). Who gives? A literature review of predictors of charitable giving part one: Religion, education, age and socialisation. Voluntary Sector Review, 2(3), pp. 337-365.

BfS. (2014a). Öffentliche Finanzen: Steuern, Einnahmen. Retrieved October 14, 2014, from http://www. bfs.admin.ch/bfs/portal/de/index/themen/18/02/blank/key/steuerbelastung_kantone.html.

BfS. (2014b). Statistisches Lexikon. Retrieved October 14, 2014, from http://www.bfs.admin.ch/bfs/ portal/de/index/themen/04/02/05/key/gesamtes_volkseinkommen.html.

Cooper, K. (1994). Nonprofit-Marketing von Entwicklungshilfe-Organisationen. Grundlagen-Strategien-Massnahmen. Wiesbaden: Deutscher Universitäts-Verlag.

Eckhardt, B., Jakob, D., \& von Schnurbein, G. (2011). Der Schweizer Stiftungsreport 2011. Basel, Zürich: Centre for Philanthropy Studies (CEPS), Zentrum für Stiftungsrecht, SwissFoundations

Eckhardt, B., Jakob, D., \& von Schnurbein, G. (2012). Der Schweizer Stiftungsreport 2012. Basel, Zürich: Centre for Philanthropy Studies (CEPS), Zentrum für Stiftungsrecht, SwissFoundations

Eckhardt, B., Jakob, D., \& von Schnurbein, G. (2014). Der Schweizer Stiftungsreport 2014. Basel, Zürich: Centre for Philanthropy Studies (CEPS), Zentrum für Stiftungsrecht, SwissFoundations 
Feld, L. P., \& Frey, B. S. (2010). Tax evasion and the psychological tax contract. In J. Alm, J. MartinezVazquez, \& B. Torgler (Eds.), Developing alternative frameworks for explaining tax compliance (pp. 74-94). London: Routledge.

Feld, L. P., \& Matsusaka, J. G. (2003). Budget referendums and government spending: Evidence from Swiss Cantons. Journal of Public Economics, 87(12), 2703-2724.

Fischer, J. A. V. (2005). The impact of direct democracy on society. Bamberg: DIFO Druck OHG.

Frank, R. (1996). Motivation, cognition, and charitable giving. In J. B. Schneewind (Ed.), Giving: Western ideas of philanthropy (pp. 130-152). Bloomington and Indianapolis: Indiana University Press.

Frey, B. S. (1997). Markt und Motivation. Wie ökonomische Anreize die (Arbeits-)Moral verdrängen. München: Vahlen.

Frey, B. S., \& Torgler, B. (2007). Tax morale and conditional cooperation. Journal of Comparative Economics, 35(1), 136-159.

Haibach, M. (2006). Handbuch Fundraising. Spenden, Sponsoring, Stiftungen in der Praxis. Frankfurt, New York: Campus.

Helmig, B., \& Hunziker, B. (2007). Stiften in der Schweiz. Eine empirische Untersuchung über die Beweggründe von Stifterinnen und Stiftern. Freiburg: Verbandsmanagement Institut.

Helmig, B., Lichtsteiner, H., \& Gmür, M. (2010). Der Dritte Sektor der Schweiz. Länderstudie zum Johns Hopkins Comparative Nonprofit Sector Project (CNP). Bern, Stuttgart, Wien: Haupt.

Hopt, K. J., von Hippel, T., Anheier, H. K., Then, V., Ebke, W., Reimer, E., \& Vahlpahl, T. (2009). Feasibility Study on a European Foundation Statute: Final report

Jensen, M. C., \& Meckling, W. H. (1976). Theory of the firm: Managerial behavior, agency costs and ownership structure. Journal of Financial Economics, 3(4), 305-360.

Kinsey, K. A. (1992). Deterrence and alienation effects of IRS enforcement: An analysis of survey data. In J. Slemrod (Ed.), Why people pay taxes: Tax compliance and enforcement (pp. 259-285). Ann Arbor: University of Michigan Press.

Kirchgässner, G. (2007). Direkte Demokratie, Steuermoral und Steuerhinterziehung: Erfahrungen aus der Schweiz. Perspektiven der Wirtschaftspolitik, 8(1), 38-64.

Kirchgässner, G., \& Pommerehne, W. W. (1996). Tax harmonization and tax competition in the European Union: lessons from Switzerland. Journal of Public Economics, 60(3), 351-371.

Lindahl, W. E., \& Conley, A. T. (2002). Literature review: Philanthropic fundraising. Nonprofit Management \& Leadership, 13(1), 91-102.

Monroe, K. R. (1996). The heart of altruism: Perception of a common humanity. Princeton: Princeton University Press.

Odendahl, T. (1990). Charity begins at home: Generosity and self-interest among the philanthropic elite. New York: Basic Books.

Ostrower, F. (1997). Why the wealthy give: The culture of elite philanthropy. Princeton: Princeton University Press.

Pedrini, M., \& Minciullo, M. (2011). Italian corporate foundations and the challenge of multiple stakeholder interests. Nonprofit Management and Leadership, 22(2), 173-197.

Petrovits, C. M. (2006). Corporate-sponsored foundations and earnings management. Journal of Accounting and Economics, 41(3), 335-362.

Powell, W. W. \& Steinberg, R. (2006). The non-profit sector: A research handbook (2nd ed.). New Haven, London: Yale University Press.

Prewitt, K. (1999). The importance of foundations in an open society. In Bertelsmann Foundation (Ed.), The future of foundations in an open society (pp. 17-29). Gütersloh: Bertelsmann Foundation.

Prewitt, K. (2001). The foundation mission: Purpose, practice, public pressures. In A. Schlüter, V. Then, \& P. Walkenhorst (Eds.), Foundations in Europe. Society Management and Law (pp. 340-371). London: Directory of Social Change.

Prewitt, K. (2006). Foundations. In W. W. Powell \& R. Steinberg (Eds.), The non-profit sector: A research handbook (pp. 355-377). New Haven; London: Yale University Press.

proFonds. (2011). Abzugsfähigkeit von Spenden an steuerbefreite gemeinnützige Organisationen (Spendenabzug). Retrieved October 14, 2014, from http://www.profonds.org/uploads/tx_news/ Spendenabzug_2011.pdf.

proFonds. (2013). Spenden im Kanton Appenzell neu zu 20\% abzugsfähig. Retrieved October 14, 2014, from http://www.profonds.org/aktuell/interessenwahrung/interessenwahrung-archiv/detail/?tx_news_pi1 [controller]=News\&tx_news_pi1[action]=detail\&tx_news_pi1[news]=82\&cHash=d1b14bf27563a36f7 bb2f2b54f97a355. 
Purtschert, R. \& von Schnurbein, G. (2006). Transparenz im Schweizer Stiftungswesen - Stiftungen im Licht schwacher statistischer Grundlagen. In P. Egger, B. Helmig, \& R. Purtschert (Eds.), Stiftung und Gesellschaft. Eine komparative Analyse des Stiftungsstandortes Schweiz (pp. 21-35). Basel: Helbing \& Lichtenhahn.

Purtschert, R., von Schnurbein, G., \& Beccarelli, C. (2003). Visions and roles of foundations in Europe: Länderstudie Schweiz. VMI: Freiburg.

Randolph, W. C. (1995). Dynamic income, progressive taxes, and the timing of charitable contributions. Journal of Political Economy, 103(4), 709-738.

Riemer, H. M. (2001). Stiftungen im schweizerischen Recht. In K. J. Hopt \& D. Reuter (Eds.), Stiftungsrecht in Europa (pp. 511-519). Köln, Berlin, Bonn: Carl Heymanns Verlag.

Salamon, L. M., \& Anheier, H. K. (1992). Toward an understanding of the international nonprofit sector: The Johns Hopkins comparative nonprofit sector project. Nonprofit Management and Leadership, 2(3), 311-324.

Sargeant, A. (1999). Charitable giving: Towards a model of donor behaviour. Journal of Marketing Management, 15(4), 215-238.

Schatzmann, P. (2014). Corporate Foundations im Schweizer Stiftungssektor: Grundlagen - Bericht Empirie - Gestaltungsmöglichkeiten. Unpublished Master Thesis. University of Fribourg.

Smith, K. W. (1992). Reciprocity and fairness: Positive incentives for tax compliance. In J. Slemrod (Ed.), Why people pay taxes: Tax compliance and enforcement (pp. 223-250). Ann Arbor: University of Michigan Press.

Stadelmann-Steffen, I., Traunmüller, R., Gundelach, B., \& Freitag, M. (2010). Freiwilligen-Monitor Schweiz 2010. Zürich: Seismo Verlag.

Stutzer, A. (1999). Demokratieindizes für die Kantone der Schweiz (Working Paper No. 23). Zürich: Institute for Empirical Research in Economics.

Stutzer, A., \& Frey, B. S. (2000). Stärkere Volksrechte: Zufriedenere Bürger: eine mikroökonometrische Untersuchung für die Schweiz. Swiss Political Science Review, 6(3), 1-30.

Timmer, K. (2005). Stiften in Deutschland. Die Ergebnisse der Stifterstudie. Gütersloh: Verlag Bertelsmann Stiftung.

von Schnurbein, G. (2010). Die gemeinnützige Stiftung als neuer Wirtschaftsfaktor. In F. A. Schurr (Ed.), Gemeinnützige Stiftung und Stiftungsmanagement (pp. 7-28). Zürich: Schulthess.

Weisbrod, B. (1988). The nonprofit economy. Cambridge, MA: Harvard University Press.

Wiepking, P., \& Bekkers, R. (2012). Who gives? A literature review of predictors of charitable giving. Part two: Gender, family composition and income. Voluntary Sector Review, 3(2), 217-245. 